Copyright (C) 2021 by Cherkas Global University

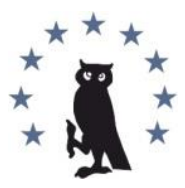

Published in the USA

Media Education (Mediaobrazovanie)

Has been issued since 2005

ISSN 1994-4160

E-ISSN 2729-8132

2021. 17(4): 664-674

DOI: $10.13187 / \mathrm{me} .2021 .4 .664$

https://me.cherkasgu.press

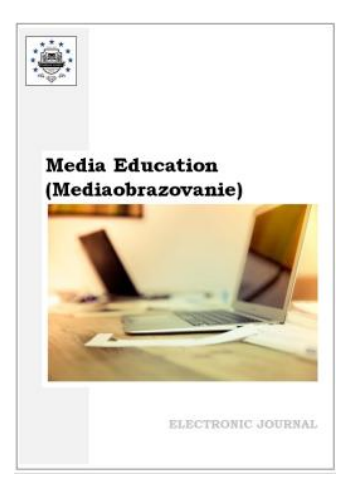

\title{
Discourse of the Development of Students' Media Literacy with Reference to Meta-subject Connections as a Platform for New Didactics: Semantic, Technological, Social Implementation Space
}

\author{
Alyona Lozovitskaya ${ }^{\text {a, }}$, Irina Goloborodko a ${ }^{\text {, Alina Semerenko }}{ }^{\text {b }}$, Olga Kravets a \\ a Rostov State University of Economics, Russian Federation \\ b Taganrog Institute of Management and Economics, Russian Federation
}

\begin{abstract}
Students' media literacy concerning the development of meta-subject connections as a key segment of new didactics is highly relevant in the context of solving the problem of enriching the content of educational policy in modern Russia. Today, the transformational processes taking place in the society bring up the problem under study to the "rank" of particular importance. In this regard, drawing active attention of the educational theorists and practitioners to the new understanding of the "media literacy" concept in the transforming realities of the new millennium is very important today. The authors' reflections on the topic of the formation of media literacy in regard to the content of the development of meta-subject connections are determined by the urgent need to disclose the semantic content of concepts, to identify integrative components and the significance of the formation process itself in the modern educational paradigm to create a holistic picture and approach of the studied content. The social, economic, informational, cultural context in correlation with the national and global peculiarities has a significant impact at the present stage.

The authors conclude that at the present stage, socio-economic, information-technological, utilitarian-pragmatic, cultural-historical contexts in their close connection with the national and global specifics have a decisive influence. In addition, the authors are convinced that the development of educational clusters that include integrative components of the phenomenon of functional literacy (information, communication, social, reading, global competencies) is an important factor of the reconstruction of the education structure, many-faceted facilitation of the educational context. Besides, media literacy is one of the key characteristics of global competencies. It seems that information and media literacy as an integrative component of functional literacy is an important quality of a modern person in an information society; media competence as a quality of a person is becoming an essential condition for successful functioning in the modern society.

Keywords: global competences, media literacy, media education, media culture, new didactics, educational policy, education development strategy, functional literacy.
\end{abstract}

\section{Introduction}

The authors of the paper carry out an integrative analysis based on the outcomes of scientific activities in terms of the problem of increasing the range of necessary conditions for the development of meta-subject connections of students under the terms of shaping and improvement of the up-to-date system of the educational setting in modern society. The theoretical field of the term "functional literacy" isconsidered from various scientific positions and its essential and semantic content is

\footnotetext{
${ }^{*}$ Corresponding author

E-mail addresses: reizend@yandex.ru (A.A. Lozovitskaya)
} 
analyzed in terms of the modern Federal State Educational Standards of Basic General Education (FSES LLC), as well as in the focus of key international studies within the framework of examining the level of students' education (Program for International Student Assessment).

The article reveals the problem of constructing an innovative educational landscape through the active use of IT tools which are considered as the means of boosting the excellence of modern education in general. The authors consider the context that represents media education as one of the key factors ensuring the development of students' meta-subject connections.

The authors' practice-oriented model is substantiated, which makes it possible to ensure effective interaction of educational establishments of various levels to create an integral educational environment that meets innovative pedagogical demands for the promotion of the digital interaction of the subjects in the educational cluster.

Several conceptual infrastructural and personnel tasks are analyzed in reference tothe formation of the digital paradigm of the global education development agenda, which acts as the main driver of strategic initiatives of modern educational policy. The conclusions formulated in the article determine the main theoretical and practice-oriented guidelines for transforming the landscape of the educational environment as a factor in the formation of human capital in the future changing society and achieving the aims of sustainable growth of the current industry.

\section{Materials and methods}

The sourcesused in this paper embrace the academic studies in the realm of the identification of the issue of the students' competencies formation (Basova, 2012; Kovaleva, 2020; Koval', 2019; Ryazanova, 2021), the results of studies devoted to the consideration of the semantic content of the concepts "functional literacy" and "meta-subject competencies" (Chigisheva, 2017; Frolova, 2016; Kirsch, Guthrie, 1977; Rudik, 2014; White,2010), UNESCO materials (UNESCO..., 1978).

Within the framework of this study, the following theoretical methods were implemented: synthesis, interpretation, isolation and systematization of essential information, comparison and generalization of information, theoretical analysis.

In turn, the methods of theoretical analysis of publications and archives on the research topic were used to describe the conceptual field of functional literacy. The descriptive and analytical method based on the fundamental standards of modern education made it possible to clarify the components of meta-subject competencies. The comparative method was used by the authors to reproduce the evaluative approach to the issue of shaping and evolution of actual ideas about the phenomenological field of the concepts of "functional literacy" and "meta-subject competences" and their components.

The emphasis on these methods in a complex made it possible to fully study the features of students' functional literacy development in regard toelaboration of meta-subject connections as a significant segment of new didactics.

\section{Discussion}

The issues of designing a high-quality modern educational environment that facilitates the elaboration of the 21st century essential skills and the efficient enhancement of the younger generation's academic and creative potential are the priorities for the state, regional and municipal bodies that regulate the activities of educational structures. The implementation of the foreground national project "Education" is aimed at updating the content of education, creating the necessary modern infrastructure, training the staff and improving their qualifications, as well as creating the necessary mechanisms for managing the sphere. To ensure the entry of the Russian Federation into the number of the leading countries in the world relating to the educational excellence, the problems of educational space formation within the digital paradigm of global development come to the fore. Aiming at improving the sphere of science and education the Strategy for the digital transformation of the science and higher education (Strategy..., 2021) was developed, within the framework of which a number of projects were presented aimed not only at the digital transformation of the industry, but also the implementation of digital strategies, which in general will ensure the modernization of educational programs which:

- combine key initiatives in the field of digitalization and the creation of the conditions necessary for the implementation of initiatives (development of the digital services, modernization of infrastructure, management of human resources and data);

- take into account the international cutting-edge trends, as well as the Russian experience in 
the online transfiguration of science and higher education;

- form a unified data management policy in the current area (including process architecture, data architecture, system architecture, infrastructure), in accordance with the foreground goals of educational policy.

The strategy outlined the key trajectories of achieving "digital maturity" for educational establishments and the field of science, which should become a tool for enhancing the education quality, introducing personalization of learning and bridging the digital divide, which in general, in our opinion, corresponds to the mainstream of current political discourse in the context of expanding the framework of international educational cooperation, which provides, in particular, the exchange of experience on digital models of education, as well as platforms for their implementation. As noted in the declaration of cooperation concluded by the Ministers of Science and Education of the G20 countries in Trieste, the foreground challenges facing the current industry in connection with the pandemic are rapidly changing requirements for specialists' professional competencies, strengthening their digital skills and ethical use of the digital potential of modern information technologies to support research collaboration, open science and higher education (Declaration..., 2021). The modern era of digitalization and an abundance of information, the active development of IT technologies and, along with this, the presence of a rather high degree of risks for educational content, determines the emergence of the need for active inclusion of media education technologies, distance and e-learning, as well as modern means of communication.

The directions of the research on the problem under consideration significantly transform the traditional cognitive paradigm, which considers learning as the transfer of a certain amount of academic knowledge, replacing it with the broad profiles of students' individual competencies, thereby declaring the transition "from the school of knowledge to the school of life." Here, in our opinion, the training of specialists with a number of narrow supra-professional skills for strengthening and reproducing national intellectual capital as a priority factor in economic growth and social progress is of particular relevance.

An essential aspect in the framework of our research is the disclosure of the essence of the concepts: "functional literacy" and "meta-subject competences".

Note that in modern research, there is a significant inconsistency of basic concepts and a variety of methodological views and concepts of the formation of meta-subject knowledge. Thus, some scientists consider the current area using the terms "hard skills" and "soft skills", which originate from scientific research in the field of military personnel training conducted by the US Army. In the process of development, the researchers revealed the importance of not only professional skills (hard skills) that can be assessed and acquired in the course of vocational education, but also universal competencies (soft skills), which are not fully amenable to testological assessment and are difficult for systematic study. The understanding of such differences in soft and hard skills was expressed in 1968 in the doctrine "Systems for the design of military training" in this way: hard skills are skills for working with equipment and machines, and soft skills are with people and papers. Note that there is another view of the emergence of the concept of rigid and flexible skills, so a number of researchers (including A.I. Ivonina, O.L. Chulanova, Yu.M. Davletshina) believe that the concept originates from analogies with English terms denoting the structure of a computer: "hardware" - computer hardware and "software" - software (Ivonina, 2017: 3).

Over time, the descriptions of "rigid and flexible skills" have firmly "settled" in the modern life of many structures and establishments, becoming a requirement for qualifications and an indicator of the competitiveness of employees, as well as an important factor in their professional development. By "hard" skills, modern researchers mean a set of professional competencies that are necessary for a specialist in a specific, narrow field. And in the clarification of the "soft skills" concept there is a strong discrepancy, depending primarily on the type of activity and profession. First of all, researchers note the key role of communication skills (readiness for communication, the ability to organize a productive dialogue and/or negotiations, the skills of active listening to the interlocutor, the ability to persuade, etc.), which are largely related to the culture of communication. Another key "soft skill" is organizational and leadership skills (responsibility, planning and goal-setting skills, punctuality and the ability to "manage" time (time management), the ability to coordinate and direct team actions, the speed of decision-making, etc.), which generally increase efficiency. In addition to the listed skills, various researchers significantly 
expand the range of "flexible skills" depending on the field of activity and the position of a person in the society. So, speaking about the field of education, some researchers move on to listing a simple set of skills that everyone needs to adapt in society - "basic skills" (Shukshina, 2019), while others will supplement the range of "flexible skills" with competencies of the 21st century (critical thinking, creativity, emotional intelligence, etc.), forming a new framework of "simple knowledge and skills of "simple skills" (Shukshina, 2019: 93).

However, considering the key goals of the development of national education, updating the fundamental documents (including Federal educational standards of basic education), as well as the priority tasks and challenges facing the industry today, we emphasize that the resolution of the identified contradictions lies in the combination of these concepts into a single conceptual and terminological complex. In modern documents reflecting the state guidelines of educational policy, the concepts of "functional literacy" and "meta-subject competencies" are most often encountered, which are often used synonymously, which, in our opinion, is erroneous and requires an analysis of the emergence, dynamic change in interpretations, as well as a description of modern content and relationship with the rest of the concepts and categories we are studying.

Considering the historical content enhancing of the concept of "functional literacy", several researchers, in particular O.P. Chigisheva (Chigisheva, 2017), P.I. Frolova, (Frolova, 2016) consider the evolution of this concept from being consolidated at the international level by UNESCO in 1957. Initially, the term "functional literacy", understood as a set of basic reading, writing and arithmetic skills (" $3 \mathrm{R}$ " reading, writing and arithmetic), serving mainly to eliminate illiteracy of the adult population, over time was separated from the concept of "literacy" and in 1965 The Congress of Ministers of Education for the Eradication of Illiteracy in Tehran was consolidated as a willingness to apply knowledge for socially significant action. Since 1978, not only social and civil, but also economic components have been added to the interpretation of the term. Now functional literacy is considered as a crucial quality of personal growth (Chigisheva, 2017: 1-10).

Some scholars are interested in the psychophysiological perspective of personality development (Hamilton, Burgess, 2011; Kirsch, Guthrie, 1977; Levine, 1982; Scribner, Cole, 1981; White, 2010) in regard to the notion "literacy".

The 1992 National Adult Literacy Survey (NALS) in the UK defined functional literacy as the ability to work with the texts, documents and digital data (National..., 2018). A number of studies by M. Orazali (Orazali, 2020), M. Kalantzis, W. Cope, E. Chan are dedicated to the problem of interpretation of the concept "functional literacy" and its role in pedagogics and new modern media environment (Kalantzis, Cope, 2020), L. Verhoeven, C. Elbro (Verhoeven, Elbro, 2020).

In addition, in the modern Russian scientific research field, the interpretation of functional literacy is presented in the Declaration of the United Nations Literacy Decade, which highlights the interconnection between the complexity of the modern conditions and the importance of digital literacy for personal and national well-being. The next aim is to ensure that individuals must be able to function fully and effectively as community members, parents, citizens and workers (Frolova, 2016: 179-185).

In opinion of E.A. Basova, functional literacy must be studied through the spectrum of fundamental communicative competencies of the individual, which play a key role in the mechanisms of developing communicative contacts (Basova, 2012).

Modern determinants of Russian education view functional literacy as a planned learning outcome that implies certain skills at all levels of education. G.S. Kovaleva (Kovaleva, 2020) uses this A.A. Leontyev, the concept of a functionally literate person, and functional literacy is considered as the ability to use all knowledge, skills and abilities that are constantly acquired during life to solve the widest possible range of life tasks in various spheres of human activity, communication and social relations (Leont'ev, 2003: 35), it is worth emphasizing that the current definition of functional literacy concept is examined in connection with the International Program for the Assessment of Educational Achievements of Students PISA.

The structure of the PISA study includes several areas of testing for 15-year-old students who have received compulsory basic general education (initially conducted in 3 areas: mathematical, natural science, reading literacy, and after becoming more complex in each new cycle: in 2012 financial literacy, in 2015 the decision problems, in 2018 global competencies, and in 2021 creativity will be supplemented to the current list), and their ability to use knowledge, skills, methods of action to solve a wide range of tasks that go beyond standard educational situations is being studied. Schoolchildren are invited to solve atypical tasks in which it is necessary to consider 
certain cases containing real problems from everyday life. The solution of such problems, as a rule, requires the use of subject knowledge to search for new solutions or methods of action outside the studied subject area, as well as the creative activity of students. A feature of the research tasks is the constant change of tasks, which excludes the possibility of "coaching" students to solve such problems. Through fixed, measurable results of the quality of indicators of functional literacy, the education system is tuned to improve and achieve higher indicators declared by the state program "Development of Education for 2018-2025", which envisages raising the position of Russia in the worldwide surveys examining the excellence of education as one of the key aims.

Undoubtedly, the connection of the educational space on globalization, an increase in the role of information and the use of distance learning technologies actualizes the solution of a number of problems that arise, in this regard, before the pedagogical community, in particular, the renewal of the scientific infrastructure, the system of project and innovation activities, and advanced training. Solving such problems, in the context of the state educational policy, will contribute to the creation of a fundamentally new ecosystem for the development and enrichment of the landscape of professional training of teachers in the context of damping the difficulties and contradictions of both the municipal, regional and federal levels (Lozovitskaya, 2021).

So, in recent years, one can observe the complication of the content-semantic content of the concept of "functional literacy" associated with the inclusion in it of such a component as "global competencies", which is considered as a specific isolated value-integrative component of functional literacy, which has its own subject content, value basis. and aimed at the formation of universal skills (soft skills) (Koval', 2019: 112-123). It is worth noting that the researchers themselves note the openness and incompleteness of the components of global competencies.

Many scientists consider media literacy as one of the key characteristics of global competencies, understanding it as the ability to find, analyze and critically evaluate media messages (Fedorov, 2007; Fedorov, Levitskaya, 2017; 2018; 2020; Fedorov, Mikhaleva, 2020; Gáliková, Tolnaiová, 2019; Kačinová, 2019; Ryazanova, 2021: 86-97; Vrabec, Bôtošová, 2020 and others).

In turn, we note that in the palette of characteristic essential segments of global competencies, supra-subject, multidimensional and multifunctional interdisciplinary concepts prevail. A natural question arises about the technological implementation of such an extensive "palette" of competencies, which requires special purposeful activity of the teaching staff of the country's educational organizations (PISA, 2018).

Thus, it can be summarized that since the middle of the last century, the issue of defining and examining the components of the concept of "functional literacy" has received a fairly wide coverage not only in program documents of the international level in the focus of the educational space, but also in the scientific research of foreign and Russian scientists.

The growing interest in the content of "functional literacy" makes it possible to clarify the interpretative originality of this concept in the sphere of education.

\section{Results}

The modern world community is developing rapidly, which poses new challenges for it that require international interaction in all spheres of human activities (Chigisheva, 2017). The Sustainable Development Goals (SDGs) are defined in the document "Transforming our world: the 2030 Agenda for Sustainable Development" by UN General Assembly (Transforming..., 2015).

Within the framework of our research, it is relevant to define the semantic boundaries of the use of the concept of "metasubject competences" (Order..., 2021).

From the data presented (Table 1), it is obvious that the terminological field of the concept of "global competencies" is identical to (in fact, complicated only by the subject content, which generally corresponds to) the content of the "meta-subject competences" field designated by the FSES of the new generation.

Besides, the following skills are highlighted as meaningful segments:

- to apply various methods, tools and queries in the search and selection of information or data from sources, taking into account the proposed educational task and specified criteria;

- to choose, analyze, systematize and interpret information of various types and forms of presentation;

- to find similar arguments (confirming or refuting the same idea, version) in various information sources;

- to choose independently the optimal form of information presentation and to illustrate the 
tasks to be solved with simple diagrams, other graphics and their combinations;

- to evaluate the reliability of information according to the criteria proposed by an educator or formulated independently;

- to memorize effectively and organize information.

Table 1. The content of the meta-subject results

\begin{tabular}{|c|c|c|}
\hline \multicolumn{3}{|c|}{$\begin{array}{l}\text { Meta-subject results of mastering the program of basic general education, including the adapted } \\
\text { one, should reflect: }\end{array}$} \\
\hline $\begin{array}{l}\text { Mastering universal educational } \\
\text { cognitive actions that ensure the } \\
\text { formation of cognitive skills in } \\
\text { students: }\end{array}$ & $\begin{array}{l}\text { Mastering universal } \\
\text { educational communicative } \\
\text { actions that ensure the } \\
\text { formation of students' social } \\
\text { skills: }\end{array}$ & $\begin{array}{l}\text { Mastering universal educational } \\
\text { regulatory actions that ensure the } \\
\text { formation of the semantic } \\
\text { attitudes of the individual and the } \\
\text { life skills of the individual: }\end{array}$ \\
\hline $\begin{array}{l}\text {-basic logical actions; } \\
\text {-basic research activities; } \\
\text { - work with information. }\end{array}$ & $\begin{array}{l}\text { - communication; } \\
\text { - joint activity. }\end{array}$ & $\begin{array}{l}\text { - self-organization; } \\
\text { - self-control; } \\
\text { - emotional intellect; } \\
\text { - acceptance of oneself and others. }\end{array}$ \\
\hline
\end{tabular}

So, the development of competencies which are necessary for a school graduate to solve the tasks in various spheres of human activity is one of the key landmarks of modern didactics today.

The increasing complexity of professional environments, the acceleration of globalization processes and the challenges of the digital environment require a serious transformation. It is not accidentally that it is the functional literacy of schoolchildren that is becoming a factor and criterion for the success of national educational systems, as well as an object of international research. However, to date, the scientific and pedagogical foundations of its formation in the process of general education have not been developed yet, the potential of social science subjects in the development of reading literacy and new competencies remains underestimated.

The concept of "new didactics" has recently been examinedwithin the framework of modernizing the traditional classroom-lesson system through the active introduction of digital educational tools and IT educational tools (Lozovitskaya, 2021: 1-12).Such social challenges radically change the traditional educational principles and establishdidactic aspects of the teacher's practical work, completely transforming his conceptual role. Today the teacher becomes a "curator of content" who must select teaching tools to stimulate the motivation of students' cognitive activity, as well as carry out an individualized approach to each student in an inclusive education. In addition, in accordance with the priority tasks of the state, the educational component of educational programs is significantly enriched, which further complicates, but, on the other hand, improves the educational environment.

Such an expansion and intensification of the tasks of the pedagogical community allows us to consider the formation of global meta-subject competences as the need to integrate all sides involved. The modern horizon and the space of innovations in education, considering the peculiarities and needs of Russian schools, set the tasks of building a practical proactive educational system meeting the needs and demands of the younger generation. The most promising technological models for the practical implementation of educational goals, in our opinion, are complex educational clusters which are supposed to facilitate the creation of special educational environment in which it will be possible to form the skills that are relevant for modern society (Figure 1).

When describing the content field of the model we are developing, we will focus on the main conditions for its implementation, which are necessary for achieving significant innovation potential.

The space in the society for the current model is represented by the multidimensional interaction of educational establishments of various levels (general education schools, higher educational institutions, establishments of additional education, sports schools, etc.). Such cooperation will allow to consolidate human resources, attract highly professional staff specialized on teaching certain subjects, conduct assessment procedures or other activities. Such interaction will significantly strengthen the methodological and analytical cooperation of specialists, which will 
generally increase the teachers' motivation and qualifications. In addition, active involvement of young and future teachers in the work of educational establishments will be effectively implemented which corresponds to the pedagogical education trends in Russia.At the same time, such an organization of cooperation will help to overcome many resource constraints of specific educational establishments, creating opportunities for more efficient use of the material and technical base and infrastructure of stakeholder institutions. Due to the active interaction of educational establishments, their prestige and competitiveness will increase, which in turn will stimulate the further implementation of innovations.

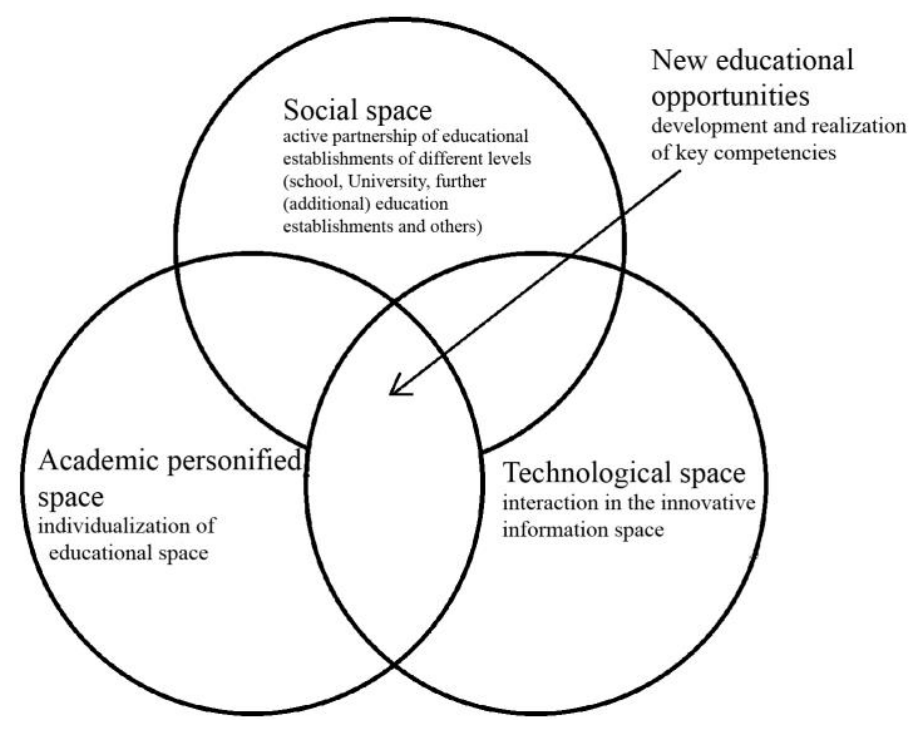

Fig. 1. The components of the innovation model of the municipal educational cluster

The theoretical space of the educational cluster we are modeling should take into account the personalization of the educational process, providing flexibility and variability of the curriculum, in order to expand the individualization of the educational route by building an individual educational trajectory for each student. Based on the system-activity approach based on the current technologies of innovative educational activities of the "new didactics" and blended learning, students can be given ample opportunity to establish their own individual educational trajectories, as well as choose additional specialized courses that can be organized both in the main educational institution and represented by educational establishments - partners in various formats (full-time, part-time, and also using the digital learning environment (DLE). The student will receive a "new facet of freedom" and the right to choose his own educational trajectory, which will allow effectively combine different forms and types of activities, fully revealing the potential of the individual, as well as reinforcing educational motivation.

Of course, for the organization of complex and multidimensional models of cooperation between educational establishments, it is necessary to significantly update the technological space and expand it in various formats, including interactive mode and remote interaction in the context of active promotion of innovations. In the activities of the educational cluster, relevant technologies can be presented in the presence of a digital educational environment, which includes educational content, digital communication tools and e-learning, which can use distance educational technologies. It is necessary to underline that a very broad and multidimensional "palette" of innovations requires a revision of the systems of organization and management of educational and upbringing processes. The educational media space today is used not only as a source of information, but also as a platform for educational activities. The mediatization of education and the subsequent integration of the education system and network space predetermined the demand for distance learning and online learning as new types of educational services. The mediatization of education and the associated expansion of the scope of educational services due to the transition to distance types of work and online learning entailed the emergence of new disciplinary structure. It seems that information literacy as an integrative component of functional literacy is the main quality of a modern personality in an information society, media competence, as an integrative quality, is becoming today an essential condition for functioning in a modern society. 
Based on the essential and semantic aspects of the described multidimensional model of cooperation between educational establishments of various levels, it becomes possible to integrate educational potential opportunities.

On the part of students:

- ample opportunities for additional and in-depth study of certain subjects; student;

- effective organization of an individual-personal approach to the educational needs of each literacy;

- formation of a wide field of meta-subject competencies, in particular functional and media

- intensive preparation for the state final certification and admission to the university;

- effective organization of project activities in accordance with interests;

- psychological adaptation to master the new social role of the student;

- promoting vocational guidance;

- increasing motivation for further training, etc.

On the part of educational establishments:

- ensuring excellence of education in the educational establishment;

- effective implementation of scientific and project activities;

- improving the quality of methodological work through the active interaction of human resources, participation in projects of various levels to promote the practice of innovative cooperation and the dissemination of the experience;

- advanced training of teachers and administrative and management personnel;

- introduction of innovations into a holistic pedagogical process;

- increasing the prestige of the educational organization and strengthening its competitiveness.

On the part of society as a whole:

- wide opportunities for additional education, greater coverage of students involved in the activities of children's public associations, clubs, circles, stations, etc.);

- the emergence of new material and technical resources (educational services, electronic databases and libraries, information portals, sharing centers, etc.);

- development, including on the basis of ICT, new methods and technologies of teaching, providing "freedom in space and time";

- improving professional training and increasing the prestige of teacher education.

Thus, the development of educational clusters is an important factor in ensuring the excellence of education, multidimensional enrichment of the educational environment as the public good and a priority "point of growth" for educational systems at the municipal, regional and federal levels.

\section{Conclusion}

The results of content analytical research provides an opportunity to highlight a number of significant inferences:

1. Modern digital technologies are radically changing the way of life of people in general, the information society is being replaced by a "project-network society". Solving the problems of expanding the conditions for high-quality and individualized education of each student in a rapidly changing world will require not only relevant scientific developments, but also the modernization of educational practices existing today. In the near future, additional theoretical and empirical research is needed to substantiate the fundamentally important "growth points" of the industry, study the psychological and pedagogical features of digital online learning, develop specific methods and comprehensive programs.

The authors of this come to the conclusion that the rapidly changing world, the strategy of active economic development of the Russian Federation, the leading role of the latest technologies and the digitalization of all aspects of public life require a significant update and increase in the efficiency of the education sector in the face of modern challenges in the formation of students' functional literacy.

2. The growing interest in the content of "functional literacy" makes it possible to clarify this concept. The authors' interpretation of the concept has qualitative variations in comparison with the existing ones. 
3. The modern concept of "functional literacy" goes beyond the simple skills of reading writing - understanding - navigating and gradually begins to include broader spheres of social and cultural life. The interpretation of the concept of "functional literacy" is made in the socioeconomic, information-technological, utilitarian-pragmatic, cultural-historical context, in their close connection with national and global specifics.

4. The development of educational clusters that include integrative components of functional literacy (information, communication, social, reading, global competencies) is an important factor in ensuring the excellence of education, multi-faceted enhancement of the educational setting.

5 . Shaping of students' functional literacy contributes to the effectiveness and adequacy of the shift in human consciousness in the era of the information revolution.

Nowadays, technology advancement outpaces society awareness of the causes and especially the consequences of its actions, society had to begin to adapt its consciousness to this acceleration.

An important result of the widespread use of information technologies is the formation of a qualitatively new informational human environment, which has become the truly "thirdidentity", complementing the usual "first" (natural) and "second" (technological) identities.

Complicating the world, information technologies reduce its cognizability by individual consciousness. A person increasingly perceives the information world, living in the physical one. In this regard, the main concern is the formation of a personality not by relatively deep experiences associated with both directly experienced events of one's life, but rather superficial experiences associated with the consumption of ready-made emotions provided by social networks and platforms. And hence: the crisis of identity, loss of historical memory, minimization of historical intergenerational ties, etc. In this context, media education of the younger generation should occupy one of the key positions in the modern education system.

\section{References}

Basova, 2012 - Basova, E.A. (2012). Formirovanie u podrostkov funktsional'noi gramotnosti $\mathrm{v}$ sfere kommunikatsii (na materiale gumanitarnykh predmetov) [Formation of functional literacy in the field of communication among adolescents (based on the material of humanitarian subjects)]: PhD. Dis. St. Peterburg. [in Russian]

Chigisheva et al., 2017 - Chigisheva, O.P., Soltovets, E.M. Bondarenko, A.V. (2017). Interpretatsionnoe svoeobrazie kontsepta "funktsional'naya gramotnost" v rossiiskoi i evropeiskoi teorii obrazovaniya [Interpretational characteristics of the concept "functional literacy" in Russian and European theory of education]. Mir nauki. 5(4): 1-10. [in Russian]

Declaration..., 2021 - Declaration of G20 Ministers on Leveraging Research, Higher Education and Digitalisation for a Strong, Sustainable, Resilient and Inclusive Recovery. [Electronic resource]. URL: https: www.g20.org/wp-content/uploads/2021/o8/G20-Ministerial-Declaration.pdf

Fedorov, 2007 - Fedorov, A. (2007). Media competence of a person: from terminology to indicators. Innovations in Education and Teaching International. 10.

Fedorov, Levitskaya, 2017 - Fedorov, A., Levitskaya, A. (2017). Comparative analysis of the indicators' levels of students' media competence development in the control and experimental groups. International Journal of Media and Information Literacy. 2(1): 16-37.

Fedorov, Levitskaya, 2018 - Fedorov, A., Levitskaya, A. (2018). Mass media literacy education in modern Russia. Media Education. 2: 6-23.

Fedorov, Levitskaya, 2018 - Fedorov, A., Levitskaya, A. (2018). Media literacy education mass media education in Commonwealth of Independent States (CIS). Media Education. 1: 7-17.

Fedorov, Levitskaya, 2020 - Fedorov, A., Levitskaya, A. (2020). Dissertation researches on media literacy education in Commonwealth of Independent States (CIS). Media Education. 6o(1): 63-99.

Fedorov, Mikhaleva, 2020 - Fedorov, A., Mikhaleva, G. (2020). Current trends in media and information literacy in research and scientific publications of the early 21st century. International Journal of Media and Information Literacy. 5(2): 153-163.

Frolova, 2016 - Frolova, P.I. (2016). K voprosu ob istoricheskom razvitii ponyatiya "Funktsional'naya gramotnost"' v pedagogicheskoi teorii i praktike [The historical development of the «functional literacy» concept in educational theory and practice]. Nauka o cheloveke: gumanitarnye issledovaniya. 1(23): 179-185. [in Russian] 
Gáliková Tolnaiová, 2019 - Gáliková Tolnaiová, S. (2019). Media and truth in the perspective of the practice and life form of the modern "homo medialis". Communication Today. 10(1): 4-19.

Hamilton, Burgess, 2011- Hamilton, M., Burgess, A. (2011). Back to the future?: functional literacy and the new skills agenda. Discussion paper [Electronic resource]. URL: http://eprints. lancs.ac.uk/66608/

Ivonina et al., 2017 - Ivonina, A.I., Chulanova, O.L., Davletshina, Y.M. (2017). Sovremennye napravleniya teoreticheskikh i metodicheskikh razrabotok v oblasti upravleniya: rol' soft-skills i hard skills $\mathrm{v}$ professional'nom i kar'ernom razvitii sotrudnikov [Modern directions of theoretical and methodological developments in the field of management: the role of soft-skills and hard skills in professional and career development of employees]. Naukovedenie. 9(1): 3-7. [in Russian]

Kačinová, 2019 - Kačinová, V. (2019). From a reductionist to a holistic model of digital competence and media education. Communication Today. 10(2): 16-27.

Kalantzis, Cope, 2020 - Kalantzis, M.W., Cope, E. (2020). Chan Functional literacy pedagogy, 146-175. [Electronic resource]. URL: https://www.researchgate.net/publication/338862496_Funct ional_literacy_pedagogy DOI: 10.1017/9781316442821.007

Kirsch, Guthrie, 1977 - Kirsch, I., Guthrie, J.T. (1977). The concept and measurement of functional literacy. Reading Research Quarterly. 13: 485-507.

Koval' et al., 2019 - Koval', T.V., Dyukova, S.E. (2019). Global'nye kompetentsii - novyi komponent funktsional'noi gramotnosti [Global competence is a new component of functional literacy]. Otechestvennaya i zarubezhnaya pedagogika. 4(61): 112-123. [in Russian]

Kovaleva, 2020 - Kovaleva, G.S. (2020). Funktsional'naya gramotnost' - sovremennyi vyzov dlya obrazovaniya» [Functional literacy - modern lyrics for education]. [Electronic resource]. URL: https://rtsiioko.rf/upload/medialibrary/193/2020.09.24_FG_Oryel.pdf [in Russian]

Leont'ev, 2003 - Obrazovatel'naya sistema "Shkola 2100". Pedagogika zdravogo smysla [The educational system "School 2100". Pedagogy of common sense]. Moscow. [in Russian]

Lozovitskaya, 2021 - Lozovitskaya, A.A. (2021). Kontseptosfera "zhivoi pedagogiki", "novoi didaktiki" i "smeshannogo obucheniya" v ramkakh konstruirovaniya innovatsionnogo obrazovatel'nogo landshafta: sushchnostno-smyslovoi i organizatsionno-pedagogicheskii aspekty analiza [The concept sphere of "living pedagogy", "new didactics" and "mixed learning" within the framework of designing an innovative educational landscape: essential-semantic and organizational-pedagogical aspects of the analysis]. Uchenye zapiski. 2(58): 1-12. [in Russian]

National..., 2018 - National Adult Literacy Survey - NALS (2018). National Adult Literacy Survey - NALS. [Electronic resource]. URL: https://nces.ed.gov/statprog/handbook/pdf/nals.pdf

Order..., 2021 - Prikaz Minprosveshcheniya Rossii ot 31.05.2021 N 287 "Ob utverzhdenii federal'nogo gosudarstvennogo obrazovatel'nogo standarta osnovnogo obshchego obrazovaniya" [Order of the Ministry of Education of the Russian Federation of 31.05.2021 N 287 "On approval of the Federal State educational standard of basic general education]. [Electronic resource]. URL: http://publication.pravo.gov.ru/Document/View/0001202107050027 [in Russian]

PISA, 2018 - PISA (2018). Funktsional'naya gramotnost': global'nye kompetentsii. Otchet po rezul'tatam mezhdunarodnogo issledovaniya PISA-2018 GK [Functional literacy: global competencies. Report on the results of the PISA-2018 International Study]. [Electronic resource]. URL: https://fioco.ru/Media/Default/Documents/\%Do\%9C\%Do\%A1\%Do\%98/\%Do\%93\%Do\%9A\%20PIS A-2018_.pdf [in Russian]

Rudik et al., 2014 - Rudik, G.A., Zhaitapova, A.A., Stog, S.G. (2014). Funktsional'naya gramotnost' - imperativ vremeni [Functional literacy-the imperative of time]. Obrazovanie cherez vsyu zhizn': nepreryvnoe obrazovanie $v$ interesakh ustoichivogo razvitiya. 1: 263-269. [in Russian]

Ryazanova et al., 2021 - Ryazanova, N.E., Morgun, D.V., Argunova, M.V. (2021). Formirovanie global'nykh kompetentsii dlya VUCA-mira: zachem, chemu i kak uchit'? [Formation of global competencies for the VUCA-world: why, than. and how to teach?]. Nauka $i$ shkola. 2: 86-97. [in Russian]

Scribner, Cole, 1981 - Scribner, S., Cole, M. (1981). The Psychology of literacy. Cambridge, Mass.: Harvard University Press. 336 p.

Shukshina, 2019 - Shukshina, Y.A. (2019). Obrazovanie XXI veka: klyuchevye kompetentsii i novaya gramotnost' [Education of the 21st century: key competences and new literacy]. Gumanitarnye nauki i obrazovanie. 1(37): 90-94. [in Russian] 
Strategy..., 2021 - Strategy of digital transformation of the branch of science and higher education [Electronic resource]. URL: https://legalacts.ru/doc/strategija-tsifrovoi-transformatsiiotrasli-nauki-i-vysshego-obrazovanija-utv/

Transforming..., 2015 - Transforming our world: the 2030 Agenda for Sustainable Development. [Electronic resource]. URL: https://sustainabledevelopment.un.org/index.php ?menu=2361

UNESCO..., 1978 - UNESCO (1978). Revised Recommendation concerning the International Standardization of Educational Statistics. General Conference of UNESCO. Paris. [Electronic resource]. URL: http://unesco.org/en/ev.php-URL_ID=13136\&URL_DO=DO_TOPIC\&URL_ SECTION=201.html

Verhoeven, Elbro, 2020 - Verhoeven, L., Elbro, C. (2020). Precursors of Functional Literacy. Focaal, 11: 17-32. [Electronic resource]. URL: https://www.researchgate.net/publication/2418 77728_Precursors_of_Functional_Literacy DOI: 10.1075/swll.11.04 elb

Vrabec, Bôtošová, 2020 - Vrabec, N., Bôtošová, L., (2020). The Concept of learning-bydoing in the context of media education and school quality assessment. Communication Today. 11(1): 140-148.

Wagner, 2010 - Wagner, D.A. (2010). Literacy. In: Bornstein, M. (ed.). Handbook of Cultural Developmental Science. NY: Taylor \& Francis.

White, 2010 - White, S. (2010). Understanding functional literacy: Connecting text features, task demands, respondent skills. New York: Routledge.

Oraza, 2020 - Oraza, M. (2020). Functional literacy in the educational system. [Electronic resource]. URL: https://www.researchgate.net/publication/349244994_Functional_literacy_in_the_ educational_systemDOI:10.47751/СКГПУ-1937-0019 